\title{
EDITORIAL
}

\section{Consideraciones acerca de la pandemia de COVID-19}

\author{
Barrios Monges, Laurentino
}

${ }^{1}$ Universidad Nacional de Asunción, Facultad de Ciencias Médicas. Asunción, Paraguay.

Nos encontramos actualmente ante una circunstancia para la salud pública mundial la cual no habíamos tenido desde hace mucho tiempo y que significa un hecho de trascendencia no solo para la ciencia médica sino para la sociedad mundial: el mundo no va a ser igual después de esta pandemia.

Con respecto a esta pandemia, nos enfrentamos a un nuevo tipo de virus, el séptimo de la familia de los coronavirus (1). El brote actual tuvo su origen en China, en la ciudad de Wuhan, región de Hubei (2). Este coronavirus fue actualmente designado por la Organización Mundial de la Salud (OMS) como SARS-CoV-2 (3). La OMS ha definido que el brote de SARS-CoV-2 se ha convertido en una pandemia en fecha 11 de marzo del corriente año (4).

Considerando la presente pandemia, debemos tener más que nunca presentes las técnicas de prevención que conocemos desde hace más de un siglo, pero que resultan difíciles hasta ahora de compartir con el público en general y que incluso a los profesionales médicos nos resulta a veces difíciles de mantener, pero que no por ello pierden su crucial importancia. El lavado de manos, propuesto desde un inicio para disminuir los casos de infecciones diversas, cobra ahora un nuevo significado en un esfuerzo mundial de la humanidad en contra de un enemigo invisible.

No debemos obviar los esfuerzos de los países en la disminución de los contagios. Algunos de los países más industrializados del mundo han detenido o llevado a mínimos sus economías (5), han implicado políticas de aislamiento obligatorio y han visto la necesidad de recurrir a métodos que no se habían usado, en algunas de ellas, desde algunos de los periodos bélicos del siglo pasado. Estas situaciones no solo tienen sus implicancias políticas y económicas, sino que representan un nuevo estresor a gran parte de la población. No todos estamos preparados para pasar semanas encerrados. Esto implica que se considere la necesidad de proveer más que nunca servicios de salud de mental y de asistencia domiciliaria a grandes sectores de la población.

Nuestro país no es ajeno a esto. Si bien nuestro sistema de salud es precario, hemos visto una cooperación intersectorial plena y la predisposición de diferentes sectores, públicos y privados en el esfuerzo nacional contra el virus. No debemos caer en fomentar el estigma contra los compatriotas que sean contagiados, no tuvieron culpa de esto ni se debe fomentar discursos que marginalicen a esta población.

Nuestro Hospital de Clínicas se ha preparado para poder afrontar este desafío. Hemos diseñado protocolos de atención a pacientes mediante un sistema de contingencia a usuarios con síntomas respiratorios. Los diferentes servicios se han preparado para brindar soporte a los pacientes, considerando las perspectivas de cada especialidad. La Universidad Nacional de Asunción ha

Autor correspondiente: Prof. Dr. Laurentino Barrios Monges. Decano de la Facultad de Ciencias Médicas, Universidad Nacional de Asunción. Asunción, Paraguay. E-mail: fcm@med.una.py.

Fecha de recepción el 23 de Marzo del 2020; aceptado el 25 de Marzo del 2020. 
contactado con las autoridades sanitarias nacionales para ofrecer la infraestructura y la capacidad profesional del Instituto de Investigación de Ciencias de la Salud (IICS) para procesar las muestras de los casos sospechosos.

No sabemos que nos depara esta pandemia, pero debemos buscar siempre mantener el rigor científico y la colaboración constante entre las entidades que prestamos servicios sanitarios. Ya hemos pasado por situaciones similares en el pasado, mantengamos las medidas de prevención y preparémonos para los desafíos que nos esperan posteriormente.

\section{Prof. Dr. Laurentino Barrios Monges}

Decano de la Facultad de Ciencias Médicas Universidad Nacional de Asunción

\section{REFERENCIAS BIBLIOGRAFICAS}

1. Corman V, Landt O, Kaiser M, Molenkamp R, Meijer A, Chu D. Detection of 2019 novel coronavirus (2019-nCoV) by real-time RT-PCR. Eurosurveillance [Internet]. 2020; Available from: https://www. eurosurveillance.org/content/10.2807/1560-7917. EN.2020.25.3.2000045

2. Chen N, Zhou M, Dong X, Qu J, Gong F, Han Y. Epidemiological and clinical characteristics of 99 cases of 2019 novel coronavirus pneumonia in Wuhan, China: a descriptive study. Lancet [Internet]. 2020 Jan 30; Available from: http://www.ncbi.nlm.nih. gov/pubmed/32007143

3. Naming the coronavirus disease (COVID-19) and the virus that causes it [Internet]. [cited 2020 Mar 23]. Available from: https://www.who.int/emergencies/ diseases/novel-coronavirus-2019/technicalguidance/naming-the-coronavirus-disease-(covid2019)-and-the-virus-that-causes-it

4. CNN JG and JH. WHO declares novel coronavirus outbreak a pandemic [Internet]. CNN. [cited $2020 \mathrm{Mar}$ 23]. Available from: https://www.cnn.com/2020/03/11/ health/coronavirus-pandemic-world-healthorganization/index.html

5. China locks down millions to contain coronavirus. Do quarantines work? - Business Insider [Internet]. [cited 2020 Jan 29]. Available from: https://www. businessinsider.com/quarantine-history-followingchina-wuhan-coronavirus-lockdowns-2020-1. 


\title{
EDITORIAL
}

\section{Considerations about the COVID-19 pandemic}

\author{
Barrios Monges, Laurentino \\ ${ }^{1}$ Universidad Nacional de Asunción, Facultad de Ciencias Médicas. Asunción, Paraguay.
}

We are currently facing challenging circumstances for global public health, which it had not happened in a long time and which means an unique situation not only for medical science, but also for the entire world: the world will not be the same after this pandemic.

In regards, we are facing a new type of virus, the seventh in the coronavirus family (1). The current outbreak originated in the city of Wuhan, Hubei region of China.(2). This coronavirus was currently designated by the World Health Organization (WHO) as SARS-CoV-2 (3). The WHO has defined that the SARS-CoV-2 outbreak has become a pandemic on March 11 of this year (4).

Considering the current pandemic, we shall bear in mind more than ever the prevention techniques that we have known for more than a century, but that until now have been difficult to share with the general public and that even we, as medical professionals, find sometimes difficult to maintain, but that does not mean that it loses its crucial importance. Hand washing, proposed from the outset to decrease cases of various infections, takes now on new meaning in a global effort of the humanity against an invisible enemy.

We shall not ignore the efforts of the countries in reducing contagion. Some of the most industrialized countries in the world have stopped or minimized their economies (5), have imposed policies of compulsory isolation and have seen the need to resort to methods that had not been used, in some of them, by some of the war periods of the last century. These situations not only have their political and economic implications, but also represent a new stressor for a large number of the population. We are not all prepared to spend weeks locked up. This implies considering the need to provide mental health and home care services more than ever to large sectors of the population.

Our country is not the exception. Even though our health system is precarious, we have seen a full intersectoral cooperation and the commitment of different sectors - public and private - in the national effort against the virus. We must not fall into promoting stigma against our nationals who become infected. They were not to blame for this nor should we encourage expressions that marginalize this population.

Our Hospital de Clínicas has been prepared to face this challenge. We have designed patient-care protocols through a contingency system for users with respiratory symptoms. The different services have been prepared to provide support to patients, considering the perspectives of each specialty. The National University of Asuncion has contacted the national health authorities to offer the infrastructure and professional capacity of the Health Sciences Research Institute (IICS) to process samples from suspected cases.

We do not know what this pandemic holds for us, but we shall always pursue to maintain scientific rigor and constant collaboration

Autor correspondiente: Prof. Dr. Laurentino Barrios Monges. Decano de la Facultad de Ciencias Médicas, Universidad Nacional de Asunción. Asunción, Paraguay. E-mail: fcm@med.una.py.

Fecha de recepción el 23 de Marzo del 2020; aceptado el 25 de Marzo del 2020. 
between the entities that provide health services. We have already gone through similar situations in the past, let us maintain preventive measures and prepare ourselves for the challenges that await us later.

\section{Prof. Dr. Laurentino Barrios Monges}

Decano de la Facultad de Ciencias Médicas Universidad Nacional de Asunción

\section{REFERENCIAS BIBLIOGRAFICAS}

1. Corman V, Landt O, Kaiser M, Molenkamp R, Meijer A, Chu D. Detection of 2019 novel coronavirus (2019-nCoV) by real-time RT-PCR. Eurosurveillance [Internet]. 2020; Available from: https://www. eurosurveillance.org/content/10.2807/1560-7917. EN.2020.25.3.2000045

2. Chen N, Zhou M, Dong X, Qu J, Gong F, Han Y. Epidemiological and clinical characteristics of 99 cases of 2019 novel coronavirus pneumonia in Wuhan, China: a descriptive study. Lancet [Internet]. 2020 Jan 30; Available from: http://www.ncbi.nlm.nih. gov/pubmed/32007143

3. Naming the coronavirus disease (COVID-19) and the virus that causes it [Internet]. [cited 2020 Mar 23]. Available from: https://www.who.int/emergencies/ diseases/novel-coronavirus-2019/technicalguidance/naming-the-coronavirus-disease-(covid2019)-and-the-virus-that-causes-it

4. CNN JG and JH. WHO declares novel coronavirus outbreak a pandemic [Internet]. CNN. [cited $2020 \mathrm{Mar}$ 23]. Available from: https://www.cnn.com/2020/03/11/ health/coronavirus-pandemic-world-healthorganization/index.html

5. China locks down millions to contain coronavirus. Do quarantines work? - Business Insider [Internet]. [cited 2020 Jan 29]. Available from: https://www. businessinsider.com/quarantine-history-followingchina-wuhan-coronavirus-lockdowns-2020-1. 